\title{
Potential Attractiveness of Soil Fungus Trichoderma Inhamatum for Biodegradation of the Glyphosate Herbicide
}

\author{
Kairat Kunanbayev ${ }^{1 *}$, Galina Churkina', Irina Rukavitsina', Nadegda Filippova', \\ Maral Utebayev ${ }^{1,2}$ \\ 1 Scientific-Production Center of Grain Farm named after. A.I. Baraev, 15, Baraev str, Shortandy-1, \\ 021601 Kazakhstan \\ 2 Tyumen State University, 6 Volodarskogo str., Tuymen, 625003, Russia \\ * Corresponding author's e-mail: kunanbayev.k.k@mail.ru
}

\begin{abstract}
The T. inhamatum F6-2014 fungus was isolated from the black soils of Northern Kazakhstan in stationary experiments with many years of herbicide use. The research was aimed at studying the biodegrading activity of T. inhamatum in relation to an herbicide with the glyphosate active ingredient, both in vitro and in situ. Under the laboratory conditions, the highest growth rate of a colony of $T$. inhamatum was observed in the reference variant, and reached $49.0 \pm 2.5 \mathrm{~mm}$. During the field experiments, a significant increase was noted in the microbial biomass (MB) on the first day in the herbicidal variants and ranged from 239.2 to $322.8 \mu \mathrm{g} / \mathrm{g}$ of soil. On the 15 th day, the level of MB in all herbicide variants increased 1.6-2.1 times, and in the reference -2.3 times. By the second month, the level of MB reduced 1.5-2.0 times in all variants. By the third month of the studies, the greatest MB decrease was noted in the reference $-82.8 \mu \mathrm{g} / \mathrm{g}$. The level of urease activity during the first day in all variants, including the reference, ranged between $0.12-0.15 \mathrm{mg} / \mathrm{g}$ of soil. On the 15 th day, a significant (3.3 times) increase in the urease activity was noted in the variants with glyphosate, compared to the reference. Subsequently, the difference in the level of enzyme activity was insignificant between the variants. The MB and the urease activity in the first fifteen days increase due to the more active decomposition of glyphosate by strain.
\end{abstract}

Keywords: T. inhamatum, biomass of microorganisms, biodestructors, fungi, glyphosate, xenobiotics, urease activity, soil.

\section{INTRODUCTION}

Glyphosate (N-(phosphonomethyl)-glycine, $\left.\mathrm{C}_{3} \mathrm{H}_{8} \mathrm{NO}_{5} \mathrm{P}\right)$ is a non-selective systemic herbicide used for fighting annual and perennial weeds [Baylis 2000, Zharikov, Spiridonov 2008]. The action of glyphosate is based on the inhibition of the enzyme that synthesizes important aromatic amino acids [Arfarita et al. 2013]. In agriculture, glyphosate is used extensively as an element of plant protection.

Most glyphosate biodegradation studies were aimed at using decomposer bacteria [Ermakova et al. 2010, Kononova, Nesmeyanova 2002, Liu et al. 1994, Shehata et al. 2013, Sviridov et al. 2015, Shushkova et al. 2012].
There are few studies of glyphosate biodegradation by fungus Trichoderma, but they are of particular interest. Trichoderma fungi are natural antagonists of the phytopathogenic microflora and are partly involved in cellulose decomposition [Arfarita et al. 2013, Bouchiat et al. 2016, Vazquez et al. 2015].

The studies performed in Northern Kazakhstan showed that the fungi of the Trichoderma genus have the cellulose-decomposing properties, and exhibit an antagonistic activity to the fungi of Alternaria spp., Bipolaris spp., and Fusarium spp. genera [Bekeshev 2010, Rukavitsyna 2006].

Currently, the research on disposing of pesticides with the use of the fungi of the Trichoderma genus is being performed. In particular, the ability 
of $T$. viride micromycete to decompose glyphosate has been discovered [Arfarita et al. 2013]. The data about the effect of insecticides on the growth of colonies of T. harzianum were obtained [Gonzalez et al. 2015]. At the same time, the information on the glyphosate decomposition with the $T$. inhamatum fungi is absent.

This work was aimed at studying the ability of T. inhamatum F6-2014 to decompose glyphosate herbicide in vitro and in situ.

\section{METHODS}

Under the laboratory conditions, clean glyphosate was used for chromatography in the concentration of 1 and $10 \mathrm{mg} / \mathrm{l}$ (Lesart, Kazakhstan). Under the field conditions, the Tornado Plus herbicide was used in the form of an aqueous solution with active substance (glyphosate) in the concentration of $360 \mathrm{~g} / \mathrm{l}$ (August, Russia).

Extraction of micromycete. The strain of T. inhamatum F6-2014 fungus from the collection of the Microbiologic Laboratory of LLC Scientific and Production Center of Grain Farming n.a. A. I. Barayev was isolated from the southern carbonate black soil. Microscopic examination was performed on a light microscope with 150X magnification (Altami Bio, Russia). The fungi were cultivated on Czapek Dox agar medium $(\mathrm{pH}=4.5)$ of the following composition: $\mathrm{C}_{6} \mathrm{H}_{22} \mathrm{O}_{11}-30.0 \mathrm{~g}$ (Sigma - Aldrich, USA), $\mathrm{NaNO}_{3}-2.0 \mathrm{~g}$ (ZAO Unikhim, Russia), $\mathrm{K}_{2} \mathrm{HPO}_{4}$ - to $1.0 \mathrm{~g}$ (ZAO Unikhim, Russia), $\mathrm{MgSO}_{4}-0.5 \mathrm{~g}$ (ZAO Unikh$\mathrm{im}$, Russia), $\mathrm{KCl}-0.5 \mathrm{~g}$ (Michael chemicals plant, Russia), $\mathrm{FeSO}_{4}-0.01 \mathrm{~g}$ (Mikhailovsky Plant of Chemical Reactants, Russia), and agar $15.0 \mathrm{~g}$ (Sigma - Aldrich, USA) in $1,000 \mathrm{ml}$ of water. The solution was sterilized at $1 \mathrm{~atm} .\left(121^{\circ} \mathrm{C}\right)$ for $20 \mathrm{~min}$ in an autoclave (GC-100-3, Russia). Incubation was performed for $7-10$ days in a thermostat (TS-1/80 SPU, Russia) at $25^{\circ} \mathrm{C}$.

Studying chemotactic properties. The $T$. inhamatum F6-2014 strain was sown onto the surface in the center of a Petri dish on M9 agarose mineral medium of the following composition: $\mathrm{Na}_{2} \mathrm{HPO}_{4}-6 \mathrm{~g}$ (OOO Resurs, Russia), $\mathrm{KH}_{2} \mathrm{PO}_{4}-3 \mathrm{~g}$ (ZAO Unikhim, Russia), $\mathrm{NaCl}-$ $0.5 \mathrm{~g}$ (Mikhailovsky Plant of Chemical Reactants, Russia), $\mathrm{NH}_{4} \mathrm{Cl}-1 \mathrm{~g}$ (ZAO Unikhim, Russia), and $\mathrm{C}_{6} \mathrm{H}_{12} \mathrm{O}_{6}-15 \mathrm{~g}$ (Sigma - Aldrich, USA) in $1,000 \mathrm{ml}$. Glyphosate was introduced into the
M9 agar medium at the concentration of 1 and $10 \mathrm{mg} / \mathrm{l}$ of the medium. The reference was clean the M9 medium (without glyphosate). Petri dishes with the cultures were incubated in a thermostat (TS-1/80 SPU, Russia) at $25^{\circ} \mathrm{C}$ for 15,30 , and 45 days. In order to study the processes of inhibition or stimulation of growth of the strains, the linear growth (diameter) of fungi colonies was measured after 15,30 , and 45 days, and the growth of colonies on the medium with glyphosate was compared with the reference.

Field experiment. The destructive activity of the strain of T. inhamatum F6-2014 fungus was studied in situ on a leveled experimental field of the station of LLC Scientific and Production Center of Grain Farming n.a. A. I. Barayev (N $52^{\circ} 33$. 794 E $070^{\circ} 39.401$ '). When selecting experimental sites, the factor of soil fertility variability was minimized. The area of each plot was $1 \mathrm{~m}^{2}$. The experiments were conducted in four replications according to the following scheme:

1. Liquid culture T. inhamatum (reference),

2. Liquid culture T. inhamatum + glyphosate, a single dose,

3. Liquid culture T. inhamatum + glyphosate, a double dose, and

4. Liquid culture T. inhamatum + glyphosate, a triple dose.

The experiments were laid on May 15, 2015. The fungi biomass was preliminarily accumulated in the Czapek Dox agar medium. The 30-daysold culture was introduced into the soil at the rate of $200 \mathrm{~g}$ of biomass per $1 \mathrm{~m}^{2}$. Glyphosate was introduced into the soil using a backpack sprayer at the rate of $12 \mathrm{ml}$ of glyphosate per 51 of water. Wheat was sprayed at 15 day intervals in the recommended and increased dosages. The soil samples were taken 10 days after spraying.

The MB by carbon was determined by the method of rehydration [Makarov et al. 2016]. The urease activity was determined by the method of Galstyan in Khaziyev's modification on a spectrophotometer (HACH-LANGE, Germany) [Khaziev 2005].

The arithmetic mean (M) with the standard mean (m) error was determined using Excel 2010 (Microsoft, USA); the Least Significant Difference $\left(\operatorname{LSD}_{05}\right)$ was calculated in application Agros v. 2.11 (RAAS, Russia) at the confidence level $\mathrm{p} \leq 0.05$. 


\section{RESULTS}

The T. inhamatum (strain F6-2014) fungus agar medium formed a colorless colony on the Czapek Dox, which then acquired green coloring and occupied almost the entire area of the Petri dish. Microscopy showed hyphae of various diameters from 1.5 to 8.0 microns. Thin hyphae were colorless, much-branched, septated; thick hyphae were slightly branched, with the formation of swellings and outgrowths. Conidiophores are barely noticeable, with the formation of branches of mycelium. Conidia are unicellular, globose or ellipsoidal with the size of 2.3-3.0 × 2.0-2.6 $\mu \mathrm{m}$. They are light-colored or colorless, often packed into small heads (Fig. 1).

With the development of the T. inhamatum fungus (strain F6-2014) on the M9 medium containing various concentrations of glyphosate, the changes in the growth rate of colonies were determined (see Table 1). As one can see from Table 1, the diameter of the colony in the reference variant was significantly larger than in the variants with glyphosate, reaching the maximum on the 45th day of cultivation $(72 \mathrm{~mm})$.

By the colonies growth rate, the colonies in the reference variant exceed the herbicide variants over the entire duration of the experiment. With increasing incubation time in the variants with glyphosate, growth of the colony in the variant with $1 \mathrm{mg} / \mathrm{l}$ remains unchanged. In the variant with the dosage of glyphosate of $10 \mathrm{mg} / \mathrm{l}$, positive dynamics in the growth of the colony are observed.

In the field experiments the use of glyphosate contributed to increasing the MB of microorganisms in the first days after introducing the T. inhamatum strain (Fig. 2).

An increased MB was noted in the variant with the maximum dosage of glyphosate introduction $(6.01 / \mathrm{ha})$. On day 15 , the reference variant had the greatest MB. On day 60, the level of $\mathrm{MB}$ in all variants reduced. On the third month of the study, the MB dynamics returned to the initial level (first day).

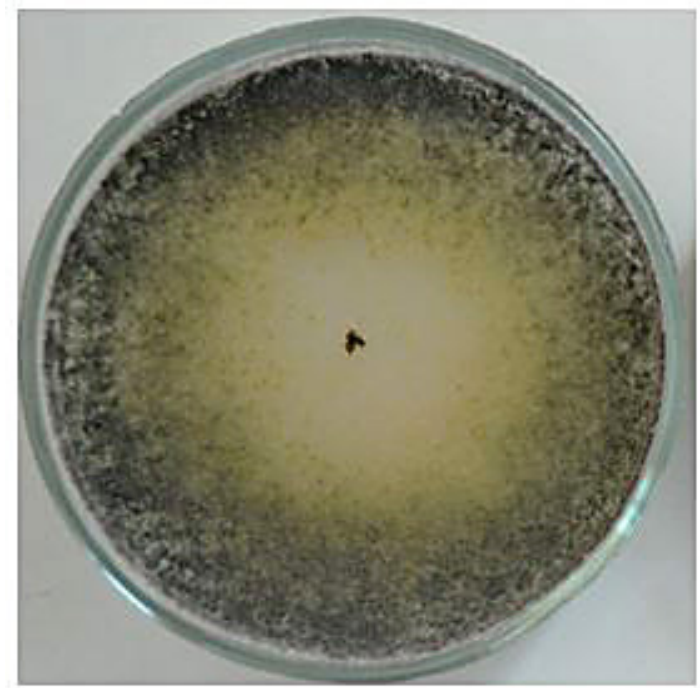

A

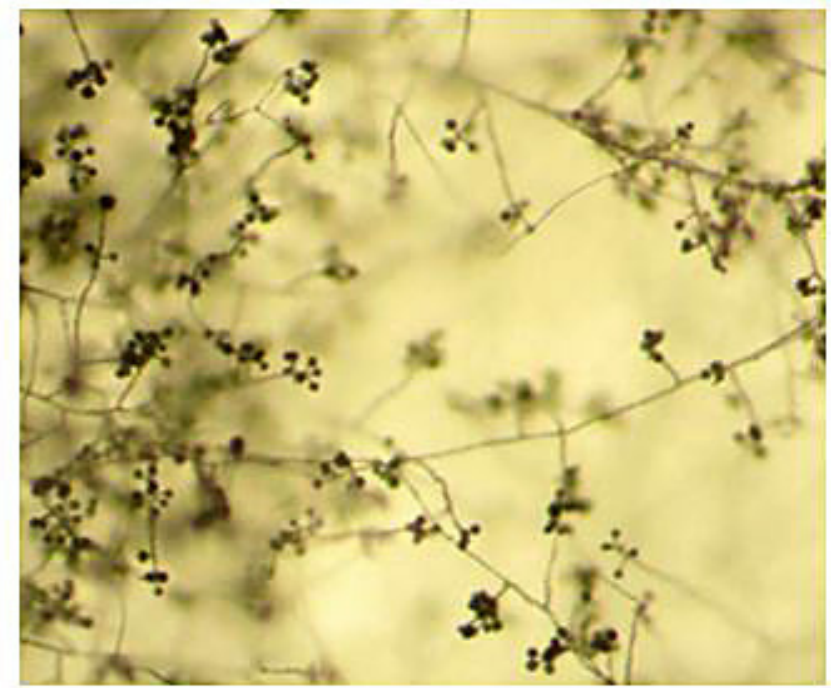

B

Figure 1. Morphology of the T. inhamatum fungus on the Czapek Dox agar medium:

*A - Aerial mycelium of fungus T. inhamatum; B - Formation of conidia of $T$. inhamatum on the 15 th day of cultivation (150x)

Table 1. The effect of glyphosate on the radial growth of the T. inhamatum colony (mm)

\begin{tabular}{|c|c|c|c|c|}
\hline \multirow{2}{*}{ Concentration of glyphosate, $\mathrm{mg} / \mathrm{l}$} & \multicolumn{3}{|c|}{ Incubation time } & LSD $_{05}$ \\
\cline { 2 - 5 } & 15 days & 30 days & 45 days & \\
\hline Reference without glyphosate & $49.0 \pm 2.5$ & $55.0 \pm 2.8$ & $72.0 \pm 3.6$ & 7.0 \\
\hline $1 \mathrm{mg} / \mathrm{l}$ & $28.0 \pm 1.4$ & $29.0 \pm 1.5$ & $29.0 \pm 1.5$ & - \\
\hline $10 \mathrm{mg} / \mathrm{l}$ & $32.0 \pm 1.6$ & $37.0 \pm 1.9$ & $41.0 \pm 2.1$ & 1.8 \\
\hline $\mathrm{LSD}_{05}$ & 8.0 & 7.0 & 2.8 & \\
\hline
\end{tabular}




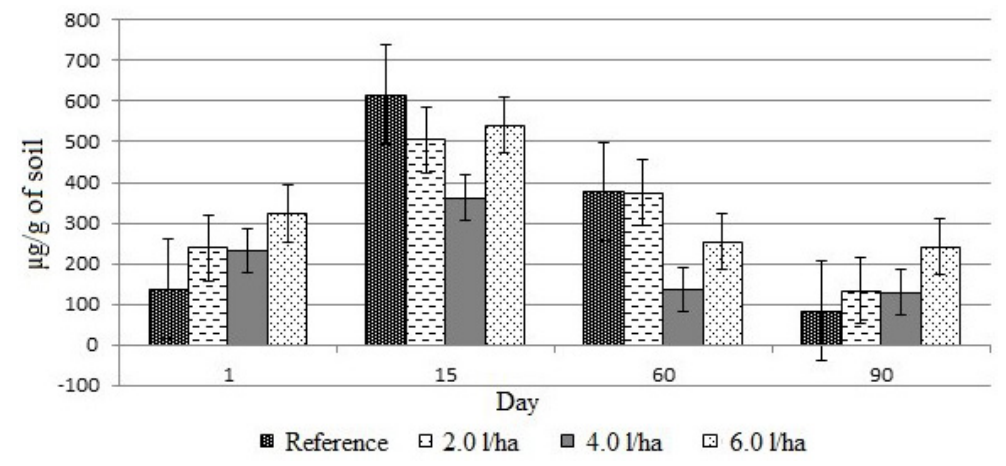

Figure 2. The dynamics of MB in the soil after the introduction of glyphosate $(p \leq 0.05)$

The urease activity characterizes the degree of organic substances mineralization. On the first day, the level of urease activity in all variants was virtually identical (Fig. 3).

In the variants with herbicides, the level of urease activity increased 3.3 times (day 15). In the reference, a high level of urease activity was noted on day 60 and remained on day 90 . The urease concentration in these periods does not exceed the reference.

\section{DISCUSSION}

In the opinion of the authors, the ability of T. inhamatum to grow in the media with glyphosate is associated with adaptation to xenobiotics. This is confirmed by the previous studies [Karasevich 1982]. The M9 medium represents a depleted nutrient medium containing mineral salts. However, the use of phosphorus in the composition of the M9 medium allows overcoming the toxic effect of glyphosate at the early stages of the colony growth. This phenomenon of cometabolism is characteristic for the whole spectrum of microorganisms, including micromycetes (Fusarium spp.
Aspergillus spp. Penicillium spp. Verticillium spp. Trichoderma spp. and Paecilomyces spp.) [Karasevich 1982, Arfartia et al. 2014]. The use of the effect of cometabolism allows a more rapid decomposition of glyphosate by strain $T$. inhamatum in the laboratory conditions.

The growth of the colony has its limits determined by the limited number of nutrients, and by the accumulation of metabolic products in-vitro.

The use of glyphosate stimulated the MB growth under the field conditions. This could be contributed to by the chemical composition of the herbicide and by the low toxicity of the preparation. Some researchers believe that the growth of MB dynamics is associated with the chemical composition of the herbicide and its application dosage [Chen et al. 2014, Qinglin Chen et al. 2015, Barman, Das 2015, Lancaster et al. 2008]. The high application rate of the preparation $(6.0 \mathrm{l} / \mathrm{ha})$ resulted in increasing the MB on the first day and on day 90. No significant relationship between the glyphosate application dosage and MB was noted. However, some researchers believe that the rate of the chemical preparation application has a dominant effect on the MB growth [Wardle, Parkinson 1990, Matt, Busse 2001]

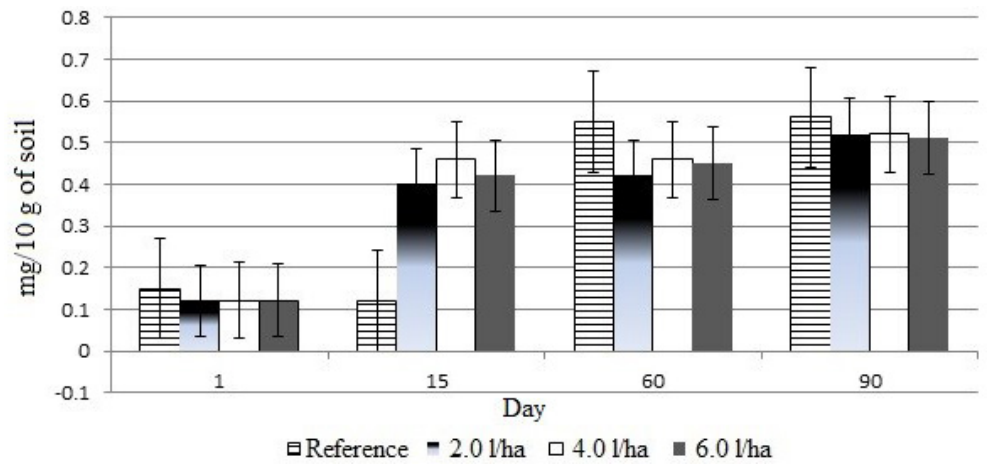

Figure 3. The dynamics of changes in the urease activity after the introduction of glyphosate $(\mathrm{p} \leq 0.05)$ 
The results of field experiments show a significant increase in the urease activity in the variants with glyphosate on day 15 . Next, the levels of enzymatic activity in all variants equalize. Presumably, this is due to the degree of toxicity of the preparation. According to the opinion of some researchers, the effect of herbicides does not increase the urease activity [Baćmaga et al. 2015]. However, the contradictory results obtained in the research require a more detailed study of this issue.

One of the main mechanisms of microorganisms' adaptation to pesticides is changing the permeability of the cell wall. The result of this mechanism is the availability of substrate molecules with intracellular enzymes, and, consequently, changes in the urease activity [Gianfreda et al. 2012].

\section{CONCLUSION}

The studies showed that $T$. inhamatum F6-2014 can grow on mineral medium M9 with the concentration of glyphosate of 1.0 and $10.0 \mathrm{mg} / 1$.

On the background of liquid culture of $T$. inhamatum (strain F6-2014) in the variants with the introduction of the herbicide, a 3.3-fold increase in urease activity and a 2.3-fold increase in MB were observed in the first 15 days. The results of the research showed the possibility of using T. inhamatum F6-2014 as a potential biological decomposer under the conditions of strong soil contamination with glyphosate.

\section{Acknowledgments}

The work was completed within the grant project of the Science Committee at the Ministry of Science and Education of the Republic of Kazakhstan "Biotechnological Methods of the Biological Degradation of Pesticides during their Long-Term Use in Agriculture in the Conditions of Climate Change". Registration No. 0113 PK00835.

BR05236351 "Environmental Risk Management in Grain Production Based on Various Degrees of Agriculture Intensification for Preventing Adverse Effects on the Public Health and the Environment", 2018-2020.

\section{REFERENCES}

1. Baylis A.D. 2000. Why glyphosate is a global herbicide: strengths, weaknesses and prospects. Pest Management Science, 56 (4), 299-308.

2. Zharikov M. G., Spiridonov Y. Y. 2008. Izuchenie vliyaniya glifosatsoderzhashchikh gerbitsidov na agrotsenoz [Studying the effect of glyphosate-containing herbicides on the agrocenosis]. Agricultural chemistry, 8, $81-89$.

3. Arfarita N., Imai T., Kanno A., Yarimizu T., Sun X. F., Wei J., Higuchi T., Akada R. 2013. The potential use of Trichoderma viride FRP3 in biodegratdion of the herbicide glyphosate. Biotechnology \& Biotechnological Equipment, 27(1), 3518-3521 (doi: 10.5504/BBEQ.2012.0118).

4. ErmakovaI.T., Kiseleva N.I., Shushkova T., Zharikov M., Zharikov G.A., Leontievsky A.A. 2010. Bioremediation of glyphosate-contaminated soils. Applied Microbiology and Biotechnology, 88(2), 585-594. (doi.org/10.1007/s00253-010-2775-0).

5. Kononova S.V, Nesmeyanova M. 2002. Phosphonates and their degradation by microorganisms. Biochemistry. Biokhimiia, 67(2), 184-195. (doi:10.1023/A:1014409929875).

6. Liu CM., McLean P.A., Sookdeo C.C., Cannon, F.C. 1991. Degradation of the herbicide glyphosate by members of the family Rhizobiaceae. Applied and Environmental Microbiology, 57(6), 1799-1804.

7. Shehata A.A., Schrödl W., Aldin A.A., Hafez H.M., \& Krüger M. 2013. The effect of glyphosate on potential pathogens and beneficial members of poultry microbiota in vitro. Current Microbiology, 66(4), 350-358. (doi:10.1007/s00284-012-0277-2).

8. Sviridov A.V., Shushkova T.V., Ermakova I.T., Ivanova E.V., Epiktetov D.O., Leontievsky A.A. 2015. Microbial Degradation of Glyphosate Herbicides (Review). Applied Biochemistry and Microbiology, 51(2), 183 - 190. (doi:10.7868/ S0555109915020221).

9. Shushkova T.V., Ermakova I.T., Sviridov A.V., Leontievsky A.A. 2012. Biodegradation of Glyphosate by Soil Bacteria: Optimization of Cultivation and the Method for Active Biomass Storage. Microbiology, 81(1), 44-50 (doi: 10.1134/S0026261712010134).

10. Bouchiat R., Veignie E., Grizard D., Soebert C., Vigier M., Rafin C. 2016. Ability of filamentous fungi to degrade four emergent water priority pollutants. Desalination and Water Treatment, 57(15), 6740-6746 (doi: 10.1080/19443994.2015.1013508).

11. Vazquez M.B., Barrera V., Bianchinotti V. 2015. Molecular identification of three isolates of Trichoderma harzianum isolated from agricultural soils in Argentina, and their abilities to detoxify in vitro metsulfuron methyl. Botany, 93(11), 793-800 (doi: 10.1139/cjb-2015-0085). 
12. Bekeshev N. S. 2010. Biologicheskie osobennosti gribov roda Trichoderma i ispolzovanie ikh v selskokhozyaistvennoi praktike [Biological features of fungi of genus Trichoderma and using them in agricultural practice]. Abstract of Cand. Diss. Astana.

13. Rukavitsyna I. V. 2006. Alternarioz, fuzarioz, gelmintosporioz pshenitsy, vozdelyvaemoi na chernozemakh stepnoi zony Severnogo Kazakhstana [Alternaria blight, Fusarium blight, helminthosporiosis of the wheat grown on the black soils in the steppe zone of Northern Kazakhstan]. Diss. Cand. Biol. Sciences, Astana.

14. Gonzalez L.C., Nicao M. E.L., Muino B.L., Perez R.H., Sanchez D.G. 2015. In vitro effect of comercial pesticides on Trichoderma harzianum strain A-34. Revista De La Facultad De Ciencias Agrarias, 47(2), 185-196.

15. Makarov M.I., Malysheva T.I., Maslov M.N., Kuznetsova E.Y., Menyailo O. V. 2016. Determination of carbon and nitrogen in microbial biomass of southern-Taiga soils by different methods. Eurasian Soil Science, 49(6), 685-695 (doi: 10.1134/ S1064229316060053).

16. Khaziev F. H. 2005. Fermentativnaya aktivnost pochv [Enzymatic activity of soils]. Moscow. (ISBN 5-02-033940-7).

17. Karasevich Y. N. 1982. Osnovy selektsii mikroorganizmov, utiliziruiushchikh sinteticheskie organicheskie soedineniia [Fundamentals of selecting microorganisms that decompose synthetic organic compounds]. Moscow, Nauka.

18. Arfartia N., Imai T., Prasetya B. 2014. Potential use of soil-born fungi isolated from treated soil in Indonesia to degrade glyphosate herbicide. Journal of degraded and mining lands management, 1(2), 63-68 (doi: 10.15243/jdmlm.2014.012.063).

19. Chen Q.L., Wang H., Yang B.S., He F. 2014. The combined effects of atrazine and lead $(\mathrm{Pb})$ : relative microbial activities and herbicide dissipation. Ecotoxicology and Environmental Safety, 102, 93-99 doi:10.1016/j.ecoenv.2014.01.011).

20. Qinglin Chen B.Y., Hui Wang, Fei He, Yongchao Gao, Ryan A. Scheel. 2015. Soil microbial community toxic response to atrazine and its residues under atrazine and lead contamination. Environmental Science and Pollution Research, 22(2), 996-1007 (doi:10.1007/s11356-014-3369-7).

21. Barman S., Das A. C. 2015. Residual effect of pre-emergence herbicides on microbial activities in relation to mineralization of $\mathrm{C}, \mathrm{N}$ and $\mathrm{P}$ in the Gangetic alluvial soil of West Bengal, India. Environ Monit Assess, 187(7), 465 (doi:10.1007/ s10661-015-4698-9).

22. Lancaster S.H., Haney R.L., Senseman S.A., Kenerley C.M., Hons F.M. 2008. Microbial degradation of fluometuron is influenced by roundup weather MAX. J Agric Food Chem., 56(18), 85-93 (doi 10.1021/jf801648w).

23. Wardle D.A., 1990. Parkinson D. Effects of three herbicides on soil microbial biomass and activity. Plant and Soil, 122(1), 21-28 (doi: 10.1007/ BF02851906).

24. Matt D. Busse A.W. 2001. Glyphosate toxiciety and the effects of long-terms vegetation control on soil microbial communities. Soil Biology and Biochemistry, 33, 1777-1789 (doi: 10.1016/ S0038-0717(01)00103-1).

25. Baćmaga M., Borowik A., Kucharski J., Tomkiel M., Wyszkowska J. 2015. Microbial and enzymatic activity of soil contaminated with a mixture of diflufenican + mesosulfuron-methyl + iodosulfuronmethyl-sodium. Environ Sci Pollut Res Int., 22(1), 643-656 (doi: 10.1007/s11356-014-3395-5).

26. Gianfreda I., Rao M.A., Mora M. 2012. Enzymatic activity as influenced by soil mineral and humic colloids and its impact on biogeochemical processes. Resource Management and Environmental Impacts. Handbook of Soil Sciences. CRC Press, Taylor and Francis. 